\title{
Trustworthiness and Fulfilled Commitment in the Supplier-SMEs Relationship
}

\author{
Sesilya Kempa ${ }^{1}$, Alberthus Sandhy Pramana Santoso ${ }^{2}$, Widjojo Suprapto ${ }^{3}$ \\ \{sesilya.kempa@petra.ac.id ${ }^{1}$, sandhy_albertus@yahoo.com², joe.suprapto@gmail.com ${ }^{3}$ \} \\ Petra Christian University, Siwalankerto 121-131 123
}

\begin{abstract}
Strong global competition demands a strong relation and maintains the relationship between suppliers and small business enterprises (UKM). This study examines trust and commitment which are affected by transaction cost and supplier relations. The data were collected from business owners of UKM Kampung Kue in Surabaya, using questionnaires that were distributed to 65 respondents. The collected data were processed with a smartPLS software to get the outer model and the inner model. The results show that transaction cost has a positive and significant effect on supplier relations and trustworthiness, with $\mathrm{P}$ value of 0.000 , and trustworthiness has a positive and significant effect on fulfilled commitment, with $P$ value of 0.000 . The results also show that the strongest relationships happen between transaction cost and supplier relations, of 0.732 , and between transaction cost and trustworthiness, of 0.612 . Therefore, transparency in pricing, supply availability, and payment becomes important aspects in building partnerships for both parties.
\end{abstract}

Keywords: transaction cost, supplier relations, trustworthiness, fulfilled commitment

\section{Introduction}

Small and medium enterprises (SMEs) are growing rapidly in Surabaya, especially food and beverage business or culinary business. Based on the data from Dinas Koperasi dan UMKM Jatim (East Java Center for Cooperation and Small Medium enterprises), small medium businesses is dominated by food and beverages (F\&B) up to $60 \%$ of the total enterprises. The research of Bayu Oktavian Nugroho, the regional marketing manager of Gojek Surabaya, also mentions that over 4000 food merchants are joining Go-food, which cover $80 \%$ of the total small and medium F\&B enterprises in Surabaya [1]. These F\&B enterprises are catering a wide range of food, from main staple food to snacks.

One famous SME center for snacks is UKM Kampung Kue, which is located in East Surabaya. This center for small businesses is unique because it is supported by the local community of the kampung. Every dawn, the local residents start selling various snacks in front of their houses, from all kinds of traditional snacks to cookies [2]. Every household can make from 400 to 600 pieces of snacks [3]. The customers are mostly intermediaries who will buy and distribute the snacks to different shops and traditional markets, but some end consumers are also welcome to buy in a smaller quantity [4]. Since founded in 2005 by Ibu Choirul, the members of UKM Kampung Kue have been growing up to 65 households and have received many awards, such as Pahlawan Ekonomi Award 2014 for home industry category [5], and EVP PT Telkom award [6]. In 2017, one product, crispy almond under a brand Pawon Kue, has been exported to various countries in Asia, and sold inside the Citilink Airlines catalogue [5]. 
To meet the daily demand, this SME center depends on supply chain management to deliver the raw ingredients just-in-time for making various cakes, breads, and cookies. The suppliers and small business enterprises are inevitably having mutually dependent relationships that make each party rely on the other. To maintain the constant incoming of raw ingredients, these small enterprises collectively negotiate with several suppliers, so that the suppliers can keep the commitment. The high demand of the snack from various customers makes UKM Kampung Kue build special relations with the suppliers.

Strong competition demands strong relationships between suppliers, company internal processes, and customers. $\mathrm{Wu}$, Weng, and Huang said that all supply chain partners will make every effort to form closer relations to reduce costs and increase profits. How to maintain long-term cooperative relationships is an important issue for them [7]. Effective supply chain planning is based on information sharing and trustworthiness in relationships between partners [8]. In this situation, transaction costs will arise.

Transaction costs indicate the costs to be incurred by UKM Kampung Kue besides the cost of purchasing raw materials with suppliers. The supporting costs incurred by UKM Kampung Kue include costs related to asset investment, anticipation of unpredictable moments, and information sharing. Meanwhile, the asset specificity of UKM Kampung Kue focuses on the investment value, in the form of some capitals that have been spent by both parties to maintain the supply chain relations of raw materials. Some raw material suppliers have invested in these small enterprises by providing raw material samples and routine training for UKM Kampung Kue business owners.

This study is looking at the sustainability or commitment of the suppliers and UKM Kampung Kue, as the relationship has been built over a long period of time through the creation of trustworthiness among both parties. Trustworthiness is also interesting to examine because it may be affected by transaction cost and supplier relations. Finally, this study is going to examine the effects of transaction cost and supplier relations with the commitment of the suppliers to fulfill the agreement.

\section{Literature Review}

\subsection{Transaction cost}

Transaction costs according to Folger and Husted are economic transaction costs (economic exchange) between two independent parties that vary from the exchange process between competing goods and services. Williamson said that transaction cost theory emerged from the emergence of the market [9]. Transaction costs are costs outside the price of goods and services due to an exchange transaction, in which the cause is in the form of assets, uncertainty, and information. These transaction costs occur due to imperfect information and limitations in processing information [10]. Transaction costs are measured by three interrelated indicators, namely asset specificity, behaviorial uncertainty, and information sharing.

\subsection{Supplier relations}

The defenition of supplier relations is a systematic approach to assessing the contribution and influence of suppliers on the success of a business. This approach helps to create positive buyer-supplier relationships and determine which activities should be carried out with each 
supplier. According to Van Hoek, supplier relations is a systematic approach to developing and managing partnerships. This understanding focuses on mutual growth and social value creation with the number of major suppliers [11]. The supplier relations variable is measured by three interrelated indicators namely perceived satisfaction, partners' reputation, and perceived personal conflict [8].

\subsection{Trustworthiness}

Trustworthiness is defined as a person's positive expectations of others in a situation that involves risk. Trust also means giving up one's fate to another person or group with the desire to take risks. Trustworthiness occurs when one party has the ability and integrity to enter into a transaction with a supplier partner. Trust has been identified as one of the key factors that contributes to the success of strategic cooperation. Trust is defined as the willingness to rely on partners and the belief that partners will not take the advantage of enjoying the benefits alone [12]. Trust is an attitude to hand over responsibility to a partner based on the integrity and ability of partners to establish relationship supply chains.

\subsection{Fulfilled commitment}

The concept of fulfilled commitment as trusting partners is very important to maintain the sustainability of both parties' relationship. The committed parties believe that their relationship is an ongoing process. A fulfilled commitment is the center of all relationships between the company and its various partners. Without fulfilled commitment, business relationships and future transactions become fragile and vulnerable so a good commitment becomes the foundation for successful supply chain implementations [8]. A fulfilled commitment occurs when the company exerts all efforts to maintain a long-term relationship with partners because they are considered important for the company [7].

One trusted business relationship may require a long-term process that goes on step by step. The impact of the relationship is the reduction of uncertainty and risk, and the increase of fulfilled commitment and trustworthiness. The purpose of the fulfilled commitment is to achieve long-term competitiveness by creating a mutually beneficial situation for all parties in a wider scope that moves quickly, competitively, and globally [13]. The fulfilled commitment is a result from the trust of the two partners in maintaining their relationships that occur in the business.

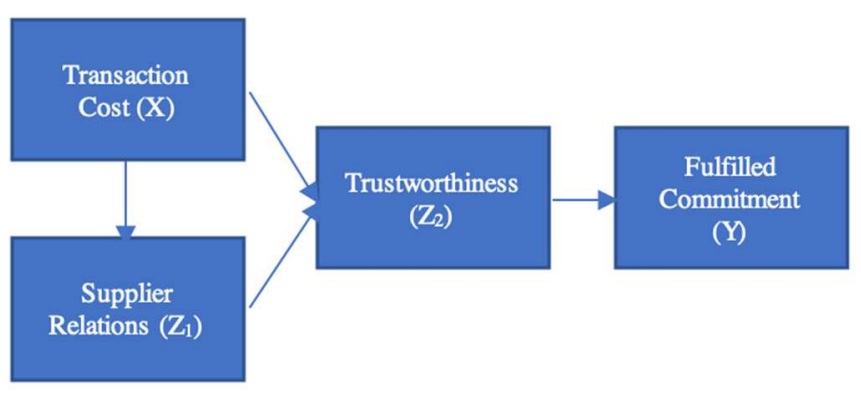

Fig.1. Research schemes 


\section{Method}

This study is using a quantitative research method. The population of this study is the UKM Kampung Kue business owners, who reside in Rungkut area of East Surabaya District. The sampling technique is using the nonprobability sampling technique, with the whole population of 65 as the respondents. This technique ensures that the samples are a real representation of the population in terms of numbers and characteristics [14]. As the number of the population is relatively small, less than 100, the whole population is included as the saturated samples [15]. Data are collected using questionnaires that are distributed to all respondents. Each item in the questionnaire is measured with 1-5 Likert Scale, from 1 as very disagree to 5 as strongly agree. Then, a smartPLS software is used to examine the research model.

\section{Results And Discussion}

The data of this study is obtained from the returned questionnaires from 65 respondents, who are the owners of small businesses under the UKM Kampung Kue. The respondents are from the range of 41 to 60 years old $(66.1 \%)$, with mostly 10 to 15 years in business $(78.5 \%)$. The business owners are dominated by women entrepreneurs.

In the questionnaire, there are 32 items to respond and all items have comply with the convergent validity test, as all loading factor values are greater than 0.7 [16]. The value of the cross loading for each variable is greater than other variables, so it also fulfills the requirement for the discriminant validity. The values of average variance extracted (AVE) and reliability tests can be observed in Table 1. The four variables have the value of AVE greater than 0.5 , so they are valid as a measuring instrument. All four variables also comply with the reliability tests, as the values of composite reliability and cronbach's alpha are greater than 0.7 .

Table 1. Construct validity and realibility

\begin{tabular}{lccc}
\hline Variable & Composite Reliability & Cronbach's Alpha & AVE \\
\hline TC $(\mathrm{X})$ & 0,928 & 0,911 & 0,617 \\
$\mathrm{SR}\left(\mathrm{Z}_{1}\right)$ & 0,939 & 0,927 & 0,632 \\
$\mathrm{~T}\left(\mathrm{Z}_{2}\right)$ & 0,933 & 0,920 & 0,582 \\
$\mathrm{CF}(\mathrm{Y})$ & 0,930 & 0,906 & 0,728 \\
\hline
\end{tabular}

The smartPLS software also surrenders the results of the inner model. The value of Rsquare for supplier relations is 0.536 , meaning that transaction costs variable affects $53.6 \%$ of the changing in supplier relations variable. The value of R-square for trustworthiness is 0.597 , meaning that the variables of transaction cost and supplier relations affect $59.7 \%$ of the changing in trustworthiness variable. The R-square value of fulfilled commitment is 0.539 , meaning that the variables of transaction cost, supply relations and trustworthiness affect $53.9 \%$ of the changing in fulfilled commitment. Based on the calculation, the Q-square value of this model is 0.6746 , indicating that this model is good because the value of goodness of fit is above zero. 


\begin{tabular}{|c|c|c|c|}
\hline \multicolumn{4}{|c|}{ Table 2. Hypothesis testing } \\
\hline Direct Effect & T-Statistics & P-Values & Remark \\
\hline $\mathrm{TC}(\mathrm{X}) \rightarrow \mathrm{SR}\left(\mathrm{Z}_{1}\right)$ & 10,868 & 0,000 & Accepted \\
\hline $\mathrm{TC}(\mathrm{X}) \rightarrow \mathrm{T}\left(\mathrm{Z}_{2}\right)$ & 4,773 & 0,000 & Accepted \\
\hline $\mathrm{SR}\left(Z_{1}\right) \rightarrow \mathrm{T}\left(Z_{2}\right)$ & 1,295 & 0,196 & Not Accepted \\
\hline $\mathrm{T}\left(\mathrm{Z}_{2}\right) \rightarrow \mathrm{FC}(\mathrm{Y})$ & 9,878 & 0,000 & Accepted \\
\hline Indirect Effect & T-Statistics & P-Values & \\
\hline$\overline{\mathrm{SR}}\left(\mathrm{Z}_{1}\right) \rightarrow \mathrm{T}\left(\mathrm{Z}_{2}\right) \rightarrow \mathrm{FC}(\mathrm{Y})$ & 1,257 & 0,209 & Not Accepted \\
\hline $\mathrm{TC}(\mathrm{X}) \rightarrow \mathrm{SR}\left(\mathrm{Z}_{1}\right) \rightarrow \mathrm{T}\left(\mathrm{Z}_{2}\right) \rightarrow \mathrm{FC}(\mathrm{Y})$ & 1,206 & 0,228 & Not Accepted \\
\hline $\mathrm{TC}(\mathrm{X}) \rightarrow \mathrm{T}\left(\mathrm{Z}_{2}\right) \rightarrow \mathrm{FC}(\mathrm{Y})$ & 4,224 & 0,000 & Accepted \\
\hline $\mathrm{TC}(\mathrm{X}) \rightarrow \mathrm{SR}\left(\mathrm{Z}_{2}\right) \rightarrow \mathrm{T}(\mathrm{Y})$ & 1,253 & 0,211 & Not Accepted \\
\hline
\end{tabular}

Some results of the inner model are presented in Table 2. The variable of transaction cost (X) has a positive and significant effect on supplier relation $\left(Z_{1}\right)$, as shown by the value of $T$ statistics of 10.868 , greater than 1.96 , and the $P$ value of 0.000 , less than 0.05 . The variable of transaction cost $(\mathrm{X})$ has a positive and significant effect on trustworthiness $\left(\mathrm{Z}_{2}\right)$, as shown by the value of $T$ statistics of 4.773 , greater than 1.96 , and the $P$ value of 0.000 , less than 0.05 . the variable of trustworthiness $\left(Z_{2}\right)$ has a positive and significant effect on fulfilled commitment (Y), as shown by the value of $\mathrm{T}$ statistics of 9.878 , greater than 1.96 , and the $\mathrm{P}$ value of 0.000 , less than 0.05 . However, the variable of supplier relations $\left(Z_{1}\right)$ has a positive but no significant effect on trustworthiness $\left(Z_{2}\right)$, as shown by the value of $T$ statistics of 1.295 , less than 1.96, and the $\mathrm{P}$ value of 0.196 , greater than 0.05 . the results also show that the variable of trustworthiness $\left(\mathrm{Z}_{2}\right)$ acts as an intervening variable between transaction cost $(\mathrm{X})$ and fulfilled commitment $(\mathrm{Y})$, as shown by the value of $\mathrm{T}$ statistics of 4.224 , greater than 1.96 , and the $\mathrm{P}$ value of 0.000 , less than 0.05 . The biggest influence lies in the relationship between transaction costs and supplier relations and transaction costs on the trustworthiness of 0.732 and 0.612 , respectively.

Activities that occur between UKM Kampung Kue and their suppliers themselves always involve finance. The finance in question consists of the cost of raw materials purchased by SMEs and costs other than raw materials. Costs other than raw materials are usually aimed at attracting SMEs not to switch to other suppliers. This cost can also be said to maintain and develop relationships. UKM players who are given a sample of raw materials, training, and clear information will be satisfied. Goods sent with good quality can also increase the supplier's reputation. Here, personal conflicts in the supplier-SME relationship will be minimized.

In their research, Kwon and Suh found that transaction costs have significant impact on trustworthiness [8]. By giving free product samples and training to small enterprises, suppliers will be considered as building trusts with small businesses because they show care to their customers. Trusts from the customers will go down if the suppliers repeatedly make the same mistakes or give wrong information. As the customers, the UKM Kampung Kue business owners still trust their suppliers. As small business enterprises, UKM owners consider the reduction in raw material transaction cost to help them grow because the UKM owners can lower the production costs. Therefore, the UKM owners maintain the good relation with their suppliers. These results are the same as those found by Kempa, Tanuwijaya, and Tarigan which state that companies that collaborate in terms of exchanging information about delivery schedules and selling prices improve quality with SMEs in providing services [17]. 
Contradicting with Kwon and Suh [8], this study found that supplier relations does not significantly affect trustworthiness. UKM owners may consider that relationship with the suppliers as trivial things, because the small enterprises may purchase smaller quantities of raw ingredients while the numbers of suppliers are abundant. When the small enterprises cannot get the best offer from one supplier, due to small quantity, the enterprises may find other suppliers with better offers. However, the business relations between suppliers and small enterprises are still beneficial for both party. One finding from this study reveals that the UKM Kampung Kue has decided to extend the cooperation with the suppliers for a longer period of time. The commitment from the SMEs to the suppliers is influenced by trustworthiness. This finding is similar to a study by Kwon and Suh, stating that trust has a positive and significant impact to fulfilled commitment [8]. Some other studies on commitment trust theory also identify that commitment is directly influenced by trust [12] [18]. Ryu, So, and Koo state that trustworthiness is important in building commitment, besides improving collaboration among two parties [19]. In this case, trust is considered as a strategic part of the partnership. Distrust can serve to reduce commitment in a relationship [8]. This fact shows that if the trust does not continue to become a follow-up fulfilled commitment, no economic gain will be gained from supply chain management.

From a supply chain perspective, a collaborative supply chain strategy between partners (supply companies) will minimize uncertainty and increase the level of trust. Open and clear communication can overcome inherent barriers to sharing information [8]. The collaborative supplier-SME relationship can result in efficiency, effectiveness, and profit-sharing for both. In this case, supply chain management requires knowledge of relationship-building skills. Supply chain integration which is known as long term strategic process and relationship management is one of the skills needed by decision-makers. To improve these skills requires intensive training and education for decision-makers. 


\section{Conclusion}

This study examines trustworthiness and commitment among the suppliers and SMEs relationship through transaction costs and supplier relations. From the results of the data processing, it can be concluded that transaction costs have a significant effect on trustworthiness. Transaction costs have a significant effect on supplier relations, too. Trustworthiness has a significant effect on fulfilled commitment, and trustworthiness acts also as an intervening variable between transaction costs and fulfilled commitment. However, supplier relations has no significant effect on trustworthiness, and supplier relations does not function as an intervening variable, too. The findings indicate if trustworthiness does not proceed into fulfilled commitment, there is no economic benefit gained from the supply chain management.

In a working relationship, the level of trustworthiness and the level of fulfilled commitment needs to be developed. The openness of information between SMEs and suppliers in terms of price, availability of supplies, and ability to pay is also an important part that needs to be considered in developing a partnership strategy between the two. All of these will ultimately result in fulfilled commitments from actions that benefit both parties which can then improve overall supply chain performance.

As this study is using the population or saturated sample, the results cannot be generalized to other SMEs. However, the model can be replicated for a bigger population to generate more reliable results for generalizing the findings. For future researches, the researcher plans to add more variables to find a better model that construct the relationship between suppliers and small business enterprises.

\section{References}

[1] S. H. Lestari, "Mayoritas pengusaha ukm makanan dan minuman di surabaya manfaatkan aplikasi go food.," Mar. 09, 2017.

[2] R. Indriani and D. Rachmawati, "Choirul mahpuduah, sosok dibalik terkenalnya kampung kue rungkut," Apr. 23, 2018.

[3] Julajuli, "Kampung kue rungkut lor, pusat wisata jajanan surabaya," Suara Surabaya, Nov. 22, 2017.

[4] C. S. Sukma, "Belanja jajanan pasar di kampung kue (1)," Oct. 06, 2014.

[5] Bogasari, "Pawon kue dari kampung kue," 2018.

[6] A. Wiraraja, "Kampung kue raih penghargaan evp pt telkom," Feb. 01, 2017.

[7] M. Wu, Y. Weng, and I. Huang, "A study of supply chain partnerships based on the commitment-trust theory," Asia Pacific J. Mark. Logist., vol. 24, no. 4, pp. 690-707, 2012, doi: $10.1108 / 13555851211259098$.

[8] I. G. Kwon and T. Suh, "Factors affecting the level of trust and commitment in supply chain relationships," J. supply Chain Manag., vol. 40, no. 2, pp. 4-14, 2004.

[9] E. Gedajlovic and M. Carney, "Markets, hierarchies, and families: Toward a transaction cost theory of the family firm," Entrep. Theory Pract., vol. 34, no. 6, pp. 1145-1172, 2010.

[10] H. Sultan and D. Rachmina, "Pengaruh biaya transaksi terhadap keuntungan usaha tani kedelai di kabupaten lamongan, jawa timur," in Forum Agribisnis, 2016, vol. 6, no. 2, pp. 161-178, doi: 10.29244/fagb.6.2.161-178.

[11] R. V Hoek, "Supplier relationship management: how key suppliers drive your company's competitive advantage." Amsterdam: PricewaterhouseCoopers Accountants NV, 2013.

[12] J. V Chen, D. C. Yen, T. M. Rajkumar, and N. A. Tomochko, "The antecedent factors on trust 
and commitment in supply chain relationships," Comput. Stand. Interfaces, vol. 33, no. 3, pp. 262-270, 2011.

[13] M. Bourlakis, T. C. Melewar, and M. A. Salam, "Supply chain commitment and business process integration," Eur. J. Mark., vol. 45, no. 3, pp. 358-382, 2011, doi: 10.1108/03090561111107230.

[14] Sugiyono, Metode penelitian pendidikan:(pendekatan kuantitatif, kualitatif dan $R \& D$ ). Bandung: Alfabeta, 2008.

[15] S. Arikunto, "Prosedur penelitian suatu pendekatan praktek," Jakarta PT Rineka Cipta, 2002.

[16] W. Abdillah and J. HM, "Partial least square (pls): alternatif structural equation modeling (sem) dalam penelitian bisnis," Yogyakarta Penerbit Andi, vol. 22, pp. 103-150, 2015.

[17] S. Kempa, N. C. Tanuwijaya, and Z. J. H. Tarigan, "The impact of supply chain collaboration in logistic service for small medium enterprise in east java, indonesia," KnE Life Sci., pp. 207216, 2020, doi: 10.18502/kls.v5i3.6573.

[18] R. C. Caceres and N. G. Paparoidamis, "Service quality, relationship satisfaction, trust, commitment and business-to-business loyalty," Eur. J. Mark., 2007.

[19] I. Ryu, S. So, and C. Koo, "The role of partnership in supply chain performance," Ind. Manag. Data Syst., vol. 109, no. 4, pp. 496-514, 2009, doi: 10.1108/02635570910948632. 